\title{
O PODER E O DIREITO
}

\section{Uma abordagem pela ótica do biopoder}

\section{Luciano Braz Silva ${ }^{1}$}

\section{RESUMO}

Analisar os aspectos do poder como formas de dominação e a sua relação com a política e o direito constitui objeto desse artigo. Neste sentido, nosso artigo antecipa suas reflexões suscitando de antemão algumas questões, tais como: haveria algum sentido para pensarmos uma coexistência entre o poder, a política e o direito? A existência/permanência do direito estaria comprometida se divorciada de uma coexistência do poder? Tomando como referencial teórico a obra de Hannah Arendt, nosso artigo direciona suas análises à concepção sistêmica do direito e da política atrelado ao conceito de poder abordado no pensamento de Luhmann.

PALAVRAS-CHAVE: Poder. Direito. Biopolitica

\section{INTRODUÇÃO}

O presente artigo traz para seu campo de reflexões três temas que embrionariamente estão atrelados a filosofia do direito, a saber, o poder, a política e o direito. Entendemos que não basta tão-somente uma nova releitura crítica a esses temas que há muito tempo já foram objeto de análises críticas por renomados filósofos do direito tanto no plano internacional como na filosofia do direito brasileira. A ordem dos tópicos não surgiu por acaso. A proposta do texto procurou oferecer um critério teleológicos para facilitar a gnosiologia do texto. Todo conhecimento cientifico se debruça sobre algum objeto e sobre

\footnotetext{
${ }^{1}$ Advogado. Doutorando em Direito pela Pontifícia Universidade Católica de São Paulo - com bolsa CNPq - sob orientação do Prof. Dr. Tercio Sampaio Ferraz Jr. Mestre em filosofia do direito pelo Centro Universitário Eurípides de Marília (UNIVEM), com Bolsa Caps. Graduado no Curso de Direito do Univem. Bolsista pela FAPESP / Iniciação Científica 2008 - 2009 com deferimento de renovação para 2010. Diretor do Diretório Acadêmico do Curso de Direito do UNIVEM 2008. Graduado no ano de 2004 no curso de Teologia pelo I.B.E.S. Integrante do Grupo de Pesquisa Científicas BIO-ÉTICA - coordenado pelo Prof. Dr. Oswaldo Giacoia Jr, nas dependências do UNIVEM. Possui cadastro no Grupo de pesquisa - Processos político-sociais e exclusão - Unesp-Marília. Pesquisador com cadastro junto ao CONPEDI - Conselho Nacional de Pesquisa e Pós-Graduação em Direito - desde 2009. Atualmente desenvolve pesquisas científicas nas áreas de Ciência Política, Teoria do Estado, Democracia, Estado Democrático de Direito, Direitos Humanos e Ética com base na filosofia habermasiana; cujas pesquisas procuram: investigar nexos recíprocos entre teoria lingüística e ética na obra de Jürgen Habermas; analisar os diálogos estabelecidos por esse filósofo com outros pensadores modernos e contemporâneos, bem como diagnosticar a influência destes na estruturação de sua filosofia; pesquisar a temática dos direitos humanos a partir da filosofia política de Habermas e do diálogo que estabelece com comunitaristas, liberais e republicanos. Pontifícia Universidade Católica de São Paulo - PUC-SP, São Paulo. Brasil. E-mail: brazadvogadoluciano@gmail.com
} 
esse objeto a ciência produz conhecimento. O homem por natureza é um ser que se relaciona com o mundo e com os demais sujeitos, ao se relacionar com algo ou com alguém, o mesmo o faz por duas razões: carência (necessidades) ou afeto. No campo da carência que visa suprir as necessidades físicas (alimentação, vestuário, proteção, moradia) estão afetas aos campos da ciências sociais aplicadas (direito, antropologia, psicologia, teologia etc) e da exata (economia, engenharia) e no campo do afeto temos a ciência da arte ou das artes. Não existiria ciência sem a ocorrência de um fenômeno que a antevê, seja no campo das exatas (física), das humanas (sociais aplicada), biológicas e etc. Portanto, neste relacionar o homem produz intercâmbios, trocas, negociações, mediações com aqueles que ajudam circunscrever seu ambiente. Aqui, encontramos a célula matriz das relações de poder que visa prover a manutenção da vida.

No primeiro tópico, a pesquisa direcionará suas análises para o elemento central que subjaz a totalidade do trabalho, a saber, o poder. Analisaremos não somente seu aspecto ontológico, mas também, sua fenomenologia, sua dinâmica. Não ambicionamos apresentar uma genealogia do poder que pudesse descreve-lo a partir duma linearidade, antes sim, analisaremos alguns aspectos ligados a sua práxis e daí tentar elucidar suas tramas, ambições, e a verossimilhança à violência e à autoridade. A primeira relação que o filho estabelece com a sua mãe não é permeada pelo afeto, pelo parentesco sanguíneo ou por uma questão religiosa, antes sim, o mesmo ao se relacionar com sua mãe só o faz com o sentido de suprir determinada carência, a saber, a manutenção da sua vida. Aqui, a priori, não há nenhum diálogo (por parte da criança), mas somente, interesse pessoal (necessidade). Trata-se de uma relação de poder, ou melhor, a criança se apodera da sua mãe, a possui como se a mesma fosse propriedade sua. Isso não difere das relações políticas, sociais-econômicas e religiosas, a posse, a sede, e o desejo de poder (dominação) subjaz as relações. Aqui há algo encoberto, uma espécie de quinta-essência do poder, uma trama que o alimenta e o identifica. Portanto, o poder se faz presente e assume relevância em primeira ordem nas relações que ocorrem nas mais variadas espécies/formas de relações entre sujeitos, grupos e comunidades. O poder como se apresenta seria algo, um objeto passível de apropriação por alguém ou por um grupo? O poder seria uma faculdade/ideologia capaz de produzir obediência? O poder poderia ser descrito como instrumento de exercício da soberania/império?

Por derradeiro, procuraremos analisar a funcionalidade da política como um instrumento à implantação e manutenção do poder. Assim, o leitor terá em mãos um diagnóstico do processo político, seu procedimento, suscitado na época moderna, através do qual a vida passou a fazer parte da política como seu objeto de apropriação. Neste sentido, o 
homem continuou a ser aquilo que outrora a filosofia aristotélica já identificara, ou seja, um ser vivo dzóe (animal) e, além disso, um ser político. O homem moderno, como veremos, é um animal em cuja política está em questão a problematização política-social que envolve sua vida de ser vivo. Isso significa dizer que para o homem moderno o processo de subjetivação impulsiona condicionalmente o indivíduo a objetivar seu próprio eu e a constituir-se como sujeito, sempre atrelado (vinculado) num horizonte constituído por um poder que exerce o domínio do controle exterior

Já caminhando para o final, a crítica se faz necessária: em que sentido o direito poderia ser destacado como uma espécie de poder? A comunicação seria um poder? Sendo um poder, poderíamos dizer que de fato há uma comunicação? Em que medida o direito pode conviver com o poder? E ainda, o poder deve ser obedecido, por quê? Todas essas perguntas não tem como causa - em primeira análise, indagar sobre uma suposta legitimidade do poder, aqui destaca-se a conotação em vista do que, deveras, algo deve ser obedecido, ou seja, sua finalidade. As atenções no campo do direito penal moderno, visam, como podemos perceber que o direito penal não se restringe, como outrora fazia, à berlinda da punição de crimes. Deveras, hoje, sua interpretação transcende a esfera da mera punição; a hermenêutica do direito penal considera como premissa elementar do seu conteúdo as razões que ditam o processo de readaptação daquele que delinquiu. Assim, o processo penal moderno deve pautar-se pelas justas medidas, sempre atrelado aos valores e princípios suscitados no Estado Democrático de Direito, correcionais contra aqueles que cometerem um crime e por conseguinte aplicar a pena como justa medida a reintegração e reabilitação do delinquente à vida política e social, ou seja, a aplicação da pena jamais poderá ter como fim sublinhar sob a identidade do delinquente a figura de um monstro social diante do julgamento da consciência pública.

Desde Hegel, a figura do culpado e do inocente tornara-se o substrato fundamental com a qual a sociedade moderna interpretou a tragédia grega. "Em todos esses conflitos trágicos”, escreveu Hegel, "devemos, antes de tudo, descartar a falsa representação de culpa ou inocência; os heróis trágicos são, ao mesmo tempo, culpados e inocentes" (HEGEL, p. 1819). Assim, o paradigma do culpado e do inocente tornou-se uma questão a ser respondida pelas lentes da biopolítica, do biopoder e da bioética. Talvez, para se chegar à pretendida realidade dos fatos, ou verdade dos fatos, nos falte ainda um ato a ser feito, a saber, virar o lado do tabuleiro.

\section{PROLEGÔMENOS DO PODER}


Desde os períodos mais remotos muitos esforços foram empregados pelos intelectuais das ciências humanas afim de descrever ou conceituar empiricamente o poder. A relevância do assunto deveu-se, e ainda nos parece relevante, considerando a realidade contumaz do poder que se revela como sendo uma prática social de diferentes formas que se articulam de maneiras variadas a pretexto da sua própria manutenção. Com isso, sua fenomenologia nos pareceu constituir tarefa para uma análise impreterível, uma tarefa incumbida àqueles que lindam com as questões ligadas a teoria do direito, a ciência política, a filosofia política e, sobretudo, com a filosofia do direito. Sabe-se que na tentativa de descrever e conceituar onto/geneologicamente o poder chegou-se a variadas contradições que nos causou mais repercussões do que, deveras, soluções práticas reais. Destarte, a realidade nos mostra que o debruçar sobre uma teoria do poder não pode se limitar/reduzir a uma interpretação descritiva ou a uma possível análise essencial do poder como condição para se obter um resultado pretendido, ou, ainda quem sabe, uma pré-consciência-técnica que nos levaria acertar um passant ou um garfos ${ }^{2}$. Dada a relevância do poder qualquer análise, que se pretenda respeitável, deverá transcender pontos isolados ou perspectivas unilaterais, ou melhor, deverá buscar conceitos mais abrangentes circunscritos em outros contextos de tal modo a possibilitar comparações e investigações conexas com outros campos.

Niklas Luhmann (1985, p. 4), em sua obra Poder (Macht) nos propõe algumas questões embrionárias fronte a temática proposta. As questões suscitadas pelo teórico arrostam indagações que lidam com os fundamentos, ou possíveis fundamentos, que procuraram examinar o poder. Daí surge, inicialmente, a possibilidade de investigar tais construções conceituais, de forma imanente, quanto à sua coerência teórica e conclusiva, considerando, todavia, verificações variadas de contingências. Segue Luhmann (1985, p. 4).

É possível perguntar, no caso de o poder dever ser um processo causal, pelos fundamentos não-causais da causalidade; no caso de ser uma troca, pelos fundamentos não permutáveis da troca; no caso de ser um jogo entre adversários, pelos fundamentos não-jogáveis do jogo. Esta técnica de questionamento permite chegar à sociedade como condição de possibilidade do poder. Ela busca uma teoria do poder através de uma teoria da sociedade.

É certo que nosso artigo não comporta uma exposição unívoca um tanto quanto pretenciosa. Toda cautela necessária nos orienta subtrair os equívocos a não nos arriscar a enfadonha e cinzenta compreensão duma suposta genealogia ou uma antologia do poder.

\footnotetext{
${ }^{2}$ Jogadas de xadrez. A tática consiste em pensar nas mais diversas possibilidades de movimentação das peças em uma determinada, ou em uma sequência de jogadas, visando sempre, seja em qual for a tática usada, capturar o rei adversário e finalizar com o jogo.
} 
Pensar uma teoria geral do poder, algo que poderia ser descrito a partir das premissas que constituem sua natureza/característica (s), ou sua/uma essência que nos possibilitaria expor e definir suas características universais, certamente, seria uma tarefa de soma zero. A razão disso nos parece muito evidente, embora haja uma descontinuidade com aquilo que normalmente se entende por teoria, ainda assim, toda teoria tem revelado uma característica de temporalidade ao que por conseguinte revelou também uma certa descontinuidade dado suas limitações e desenvolvimento acidental. Contudo, não podemos negar às análises genealógicas do poder aquilo que elas poderiam nos informar quanto a produção de relevantes deslocamentos com relação à ciência política que limita o Estado o fundamental de sua investigação sobre o poder. O fenômeno do poder, para Sampaio Ferraz (2009, p. 35), tratase de algo irredutível. Para o jus-filósofo é possível apontar o que há de mais central e oculto em seu processo, mas, “dizer-lhe o núcleo essencial é tarefa que esbarra numa sensação de multiplicidade, individual e socialmente dispersa, que nos assalta a cada passo como uma descoberta adolescente". É possível sim diagnosticarmos permeações do poder em múltiplos horizontes tais como: na economia, na religião, na política, na cultura, no direito, no campo do discurso, na persuasão, na violência, na resistência e até mesmo nas situações de fraqueza e desamparo. Consoante análise, uma questão embrionária nos salta aos olhos: por onde devemos principiar nossa análise sobre o poder?

\subsection{Poder e Violência}

Pensar ou analisar o poder condizente a uma perspectiva ontológica não poderíamos recear qualquer espanto advento. Uma análise ontológica nos remeteria para o campo dogmático/metafísico ao que por conseguinte algo muito distante das questões fenomenológicas que dizem respeito ao mundo real em que vivemos. As análises impressas nas linhas seguintes se pautarão no campo das análises fenomenológicas então distantes das concepções permeadas aos moldes duma racionalidade platônica, de modo que, o poder e a violência serão observados no âmbito da política, mais especificamente, sua fenomenologia. Em sua obra Sobre a Violência, Arendt (2017, p. 51a) ressalta certo consenso - relacionado ao fenômeno do poder - que existe entre os teóricos da política da esquerda à direita no sentido de que a violência configura-se como uma manifestação do poder. Na linha desta reflexão Arendt destaca o argumento elaborado por C. Wright Mills que teoriza o tema a partir das lentes weberiana, apontando que,

Toda política é uma luta pelo poder; a forma definitiva do poder é a violência (...), à definição de Max Weber, do Estado como "o domínio do 
homem pelo homem baseado nos meios de violência legítima, quer dizer, supostamente legítima".

Arendt (2017, p. 52a), com intelectualismo que lhe é característico, observa tal consenso como algo que lhe soa muito estranho, pois, no seu entender, "equacionar o poder político com a organização dos meios de violência, só faz sentido se seguirmos as considerações de Marx, para quem o Estado era um instrumento de opressão nas mãos da classe dominante. Seguindo em seu raciocínio, Arendt se debruça sobre as reflexões teóricas de Bertrand de Jouvenel, especificamente em seu texto, Poder, texto este muito elogiado pela cientista política. Bertrand, citado por Arendt, ressalta, da olhadela sobre o desenrolar das eras, extrai-se que as guerras se apresentam, amiúde, como uma atividade que diz respeito à própria essência do Estado. Pressupormos que com o fim da guerra teríamos também o fim dos Estados estaríamos aqui diante dum argumento falacioso? Seria certo afirmar que com o desaparecimento da violência nas relações entre os Estados estaríamos também diante do fim do Poder? A resposta para essas duas questões, como veremos, dependerá daquilo que se compreende como poder; tarefa essa esquecida pelos teóricos da ciências sociais.

Estaríamos incorrendo num erro teórico se pretendêssemos afirmar que o poder é/possui uma essência que nos levaria à (sua) uma compreensão ontológica? Ou ainda, seria possível recorrermos à uma análise genealogica do poder? Em que medida isso seria possível? O poder pode ser descrito como um instrumento de domínio e, caso assim seja definido, podemos pressupor que a sua existência se deve a um instinto de dominação? O poder, disse Voltaire referendado por Arendt (2017, p. 52a) "consiste em fazer com que os outros ajam conforme eu escolho". A priori, o poder se fará presente nas ocasiões onde o indivíduo impõe sua própria vontade como máxima equivalente que se afirma contra a resistência dos outros. Ao que tudo indica, o poder traz em sua essência o instinto de dominação que se revela como sendo um instrumento de dominação do homem sobre o homem. Enquanto dominação do homem sobre o homem, poderíamos dizer, que neste aspecto, o poder assume o aspecto da violência (?), oportunidade na qual os oponentes são compelidos a uma determinada condição de inferioridade e subalternos em relação aqueles que detêm o poder, ou seja, como já afirmamos, poder do homem sobre o homem. Aqui a violência se caracteriza como sendo um fenômeno que decorre duma patologia suscitada na esfera social e que compromete a noção/compreensão do público (espaço) e por conseguinte suplanta a compreensão e a autoconsciência da ideia de sujeito. Na medida em que a violência desempenha um papel predominante na esfera social, essa mesma esfera social passa ser diagnosticada como apolítica/anti-política e, por conseguinte, não se concebe mais a concepção de esfera pública, 
esfera essa onde a concepção de sujeito é formatada, a esfera da ação. Assim, têm-se que o limite de qualquer reflexão política é a violência e o que transcende esse marco divisor é tido como antipolítico, barbárie, guerra, violência (ARENDT, 2016, p. 45-49).

Comandar e obedecer, eis aqui a fórmula híbrida na qual o poder se constitui. Deveras argirmos como o comando se impõe e como a obediência é dada. "Se a essência do poder é a efetividade do comando, então não há maior poder do que aquele que emerge do cano de uma arma e seria difícil dizer em que medida a ordem dada por um policial é diferente daquela dada por um pistoleiro" (ARENDT, 2017, p. 53a). Nos deparamos com uma questão embrionária da qual decorrerá, dada a reflexão que se propõe, saímos da zona cinzenta conceitual. Temos que destingir, aponta Arendt (2017, p.53a), se, e em que sentido, o "poder pode ser distinguido da força, afim de descobrir como o fato de usar a força de acordo com a lei muda a qualidade da própria força", reflexão essa que nos levará a uma compreensão diferenciada naquilo que se refere as relações humanas, como elas se instituem entre os pares, como elas se convalidam; e, com isso, pelo fato de estarmos diante duma força qualificada essa força deixa de ser força. Passerim d'Entrèves, referendado por Arendt, destaca que o poder é tido como "força qualificada" ou "institucionalizada" (2017, p.54a). Quanto as análises já decorridas, conclui Arendt,

Em outras palavras, enquanto os autores anteriormente citados definem a violência como a mais flagrante manifestação do poder, Passerin d'Entrèves define o poder como uma forma de violência mitigada. Em última análise, isso vem a ser o mesmo. Será que todos, da direita à esquerda, de Bertrand de Jouvenel e Mao Tsé-tung, deveriam concordar a respeito de um aspecto tão básico da filosofia política quanto a natureza do poder?

As concepções remontam aquilo que ainda denominamos de tradições do pensamento político. Essas concepções não derivam tão-somente da velha tradição do pensamento político donde fez surgir a definição do Estado-nação, período esse que se destacou nomes como o de Jean Bodin, na França do século XVI, e Thomas Hobbes, na Inglaterra do século XVII, como sendo seus principais teóricos. Arendt (2017a, p. 54), destaca, que já no período grego essas concepções de forma de governo - domínio do homem pelo próprio homem, de um ou da maioria na monarquia e na oligarquia; dos melhores ou da maioria na aristocracia e na democracia - já fazia parte da polis grega. Por outro lado, Arendt, ressalta a existência de outra tradição e outro vocábulo não menos antigo e honrado. Quando a cidade-Estado ateniense denominou sua Constituição uma isonomia, e quando os romanos enxergaram e compreenderam a civitas como sua forma de governo, o que se viu foi uma mudança de conceito, uma metanoia política de governo da qual não concebiam mais o mando 
e a obediência como essência do poder e da lei. Esse seria o paradigma tomado pelos homens no contexto das revoluções do século XVIII quando revisitaram as velhas tradições da Antiguidade e buscaram constituir uma nova forma de governo, uma república, em que o domínio da lei seguisse/estivesse sempre assentado no poder coletivo do povo - como condição de legitimação do poder de governo - e, assim, poria fim ao domínio do homem pelo homem. Doravante, temos a devida obediência às leis e não mais obediência aos homens pelos homens - leia-se, pela força. Assim, as leis deveriam sempre prestar simpatia aos homens os quais prestariam seu consentimento. A distinção entre poder e violência é formulada por Hannah Arendt com sua maestria intelectual que é pertinente em todos seus escritos de ciência política, e aqui não é diferente, para Arendt "uma das mais óbvias distinções entre poder e violência é que o poder sempre depende dos números, enquanto a violência, até certo ponto, pode operar sem eles, porque se assenta em implementos". Assim, temos que a forma extrema do poder é caracterizada quando todos se voltam contra um, e por outro lado, a forma extrema da violência seria aquela situação onde um se volta contra todos. Com pesar, trata-se de um triste reflexo, aponta Arendt (2017a, p. 59), o real estado da ciência política que "nossa terminologia não distinga palavras-chave tais como 'poder', 'vigor', força, 'autoridade', e, por fim, 'violência.",

A prática imprecisa e o cotidiano que nos é apresentado revela o uso indistinto desses termos/substantivos. A aleatoriedade quanto ao uso desses termos revela algo que não nos parece surpreendente e sim uma certa surdez intelectual ou uma miopia de esclarecimento conceitual epistemológico e, que por sinal, comprometedora do entendimento. O uso correto dessas noções não é apenas questão de gramática lógica, mas também de perspectiva histórica. Usá-las indistintamente como sinônimos, os quais nos remeteriam a um único significado, torna impreciso qualquer argumentação que se pretenda esclarecer quem domina quem, o uso indistinto nos conduz as denominadas zonas cinzentas do entendimento. Para Arendt, o poder nunca é propriedade de um indivíduo, pelo contrário, trata-se de algo pertencente a um grupo e se solidifica perpetuando-se desde que mantenha tal correspondência com o grupo. “Quando dizemos alguém está 'no poder', na realidade nos referimos ao fato de que ele foi empossado por um certo número de pessoas para agir em seu nome" (2017a, p. 60-61). Temos então que o poder só se configura como tal, portanto, legítimo, desde que para tanto venha ser exercido pelo povo, com o povo e para o povo. Logo, esfacelando-se a integração da qual o conceito de povo se constitui consequentemente não há que se falar em poder, ou seja, a identificação do poder só é possível desde que para tanto pressuponha-se a existência do povo. Por outro lado, quando estamos nos referindo há um 
certo poderio de alguém que elucida sua singularidade entre os demais e que o identifica, na verdade estamos aqui tratando do vigor desse indivíduo, de modo inequívoco, designa-se sua singularidade. A força, por sua vez, relaciona-se com àquilo que entendemos por capacidade, ou seja, a capacidade de alguém executar determinada atividade, isto é, energia liberada por movimentos físicos ou sociais. Já a autoridade, termo muito usado de forma corriqueira e de forma muito abusiva por aqueles que utilizam tal termo. A exemplo podemos citar aquelas que investem determinadas pessoas que fazer da autoridade um faculdade de uso pessoal, por exemplo, a relação entre pais e filhos, entre aluno e professor, do Senado romano, o eclesiástico (eclesia) da igreja. Sua insígnia, aponta Arendt, é o reconhecimento inquestionável daqueles a quem se pede que obedeçam; nem a coerção nem a persuasão não necessárias (2017a, p. 60-61).

O reconhecimento da autoridade se pressupõe obediência que atrelada ao reconhecimento elimina qualquer forma de poder ou violência. Assim, entende-se que o uso da autoridade não se vincula forças estranhas que lhes são externas, por exemplo, a coerção e a força. Onde a força é usada a autoridade em si mesmo se esfacelou, em outras palavras, fracassou. A autoridade é também incompatível com a utilização do método persuasivo a qual pressupõe igualdade e opera mediante um processo argumentativo. Logo, ao se recorrer ao método persuasivo a autoridade é colocada em suspenso. Arendt (2017, p. 129b) entende que contra a ordem igualitária da persuasão ergue-se a ordem autoritária, que é sempre hierárquica. "O maior inimigo da autoridade é, portanto, o desprezo, e o mais seguro meio para miná-la é a risada" (2017, p. 62a). Por último, a violência, é identificada pelo seu aspecto instrumental. A princípio podemos, até certo ponto, enxergar na violência algum aspecto do vigor, posto que os implementos da violência, quando utilizado, são planejados e usado como instrumentos estratégicos individuais com o propósito de dinamizar o vigor natural. Como se constata, não se olvidar dizer a forma comum da combinação de violência e poder, e nada é menos frequente do que encontra-las em sua forma pura, e, portanto, extrema. Destarte, não se segue que autoridade, poder, e, violência sejam a mesma coisa. O poder demanda uma neutralidade da vontade, neutralidade essa que seria sua causa. Aqui não estamos falando, ou propondo, exatamente uma ruptura da vontade do subalterno. Ora, pensar a existência de uma estrutura do poder e de uma decisão de poder antecipável tornaria sem sentido qualquer possibilidade de vontade do subalterno.

2. POLITIZAÇÃO DA VIA E OBJETIVAÇÃO INCIPIENTE 


\begin{abstract}
Walhausen, bem no início do século XVII, falava da "correta disciplina", como uma arte do "bom adestramento". O poder disciplinar é, com efeito, um poder que, em vez de apropriar e retirar, tem como função maior "adestrar"; ou sem dúvida adestrar para retirar e se apropriar ainda mais e melhor. Ele não amarra as forças para reduzi-las; procurar liga-las para multiplicá-las e utilizá-las num todo. Em vez de dobrar uniformemente e por massa tudo o que lhe está submetido, separa, analisa, diferencia, leva seus processos de decomposição até as singularidades necessárias e suficientes (FOUCAULT, 2014, p. 167).
\end{abstract}

Nos últimos anos de sua vida, ainda enveredado no campo das pesquisas que examina a história da sexualidade, Michael Foucault, direciona seus olhares para o campo da biopolítica, pretendendo com isso investigar a vida natural do homem no horizonte dos mecanismos e nos cálculos do poder. Foucault constata na disciplina o papel fundamental à fabricação de indivíduos; portanto, ela seria a técnica específica de um poder que em um único passe (jogada) toma o indivíduo como objeto e instrumento de seu exercício.

Não é um poder triunfante que, a partir de seu próprio excesso, pode-se fiar em seu superpoderio; é um poder modesto, desconfiado, que funciona a modo de uma economia calculada, mas permanente. Humildes modalidades, procedimentos menores, se os compararmos aos rituais majestosos da soberania ou aos grandes aparelhos do Estado. E são eles justamente que vão pouco a pouco invadir essas formas maiores, modificar-lhes os mecanismos e impor-lhes seus processos. O aparelho judiciário não escapará a essa invasão, malsecreta (FOUCAULT, 2014, p. 167).

Em $A$ vontade de Saber, Focault descreve e diagnostica o processo, iniciado na época moderna, através do qual a vida passou a fazer parte da política. Neste sentido, o homem continuou a ser aquilo que outrora a filosofia aristotélica já identificara, ou seja, um ser vivo e, além disso, um ser político. Por outro lado, o homem moderno é um animal em cuja política está em questão a problematização política-social que envolve sua vida de ser vivo. Isso significa dizer que para o homem moderno o processo de subjetivação impulsiona condicionalmente o indivíduo a objetivar seu próprio eu e a constituir-se como sujeito, sempre atrelado (vinculado) num horizonte constituído por um poder que exerce o domínio do controle exterior (FOUCAULT, p. 42-43).

Para Agamben o pioneirismo dessa temática deve ser atribuído a Karl Löwith que definiu a politização da vida como característica fundamental da política dos Estados totalitários e, ao mesmo tempo, procurou observar a relação de continuidade entre democracia e totalitarismo.

Esta neutralização das diferenças politicamente relevantes e 0 enfraquecimento da tomada de decisão intensificaram-se a partir da 
emancipação do Terceiro Estado e formação da democracia burguesa e da sua transformação em democracia industrial de massa, até ao ponto decisivo em que houve uma inversão, isto é, uma total politização (totale Politisierung) de tudo, mesmo dos domínios da vida aparentemente neutros. Foi assim que surgiu na Russia marxista um Estado do Trabalho que é mais intensamente estatal do que alguma vez foi nos Estados dos soberanos absolutos; na Itália facista surgiu um Estado corporativo que regula normativamente, para além do trabalho nacional, também o que acontece depois das horas de trabalho e toda a vida espiritual; e, na Alemanha nacional-socialista, surgiu um Estado integrante organizado, que politiza através de leis raciais mesmo a vida considerada até então privada (In: AGAMBEN, 1998, p. 116 - 117).

À luz daquilo que fora registrado pelo historicismo, a contiguidade entre democracia de massa e Estados totalitários não se fez notar a forma de uma inesperada inversão; ora, a biopolítica aos poucos fora assumindo a estruturação e a gestão da vida pública e, com isso, fora arrastando consigo a vida do homo sacer. Parece que estamos falando das duas faces duma mesma moeda, onde, por um lado, temos os espaços e as liberdades e do outro os direitos que os indivíduos conquistam nos conflitos com os poderes centrais. Deste modo, preparam sempre concomitantemente uma tácita e crescente inscrição da sua vida na ordem estatal, ao que de certo modo passam a dar ainda mais corpo à temível base do poder soberano de que se queriam libertar. Toda essa problemática se desenvolve dentre estruturas préarquitetadas que atuam invisivelmente, não com o intento de vigiar o espaço exterior, antes sim, com intento de impor um controle interior articulado e detalhado e, assim, tornar visíveis os que nela se encontram. A arquitetura seria então, um operador para a transformação do indivíduo de modo a agir sobre este estabelecendo domínio sobre seu comportamento sempre modificando-o (FOUCAULT, 2014, p. 171). Consoante afirmação da biopolítica extrai-se um diagnóstico que aponta paralelamente uma deslocação, um alargamento progressivo para além dos limites do Estado de exceção que se assenta na decisão sobre a vida nua.

Seguindo a linha do pensamento elaborado por Agamben é certo que havendo - no Estado moderno - uma delimitação que assinala o ponto em que a decisão sobre a vida se torna decisão sobre a morte e a biopolítica (tanatopolítica), pode hoje essa delimitação não ser vista como um limite entre zonas claramente distintas; hoje, essa delimitação já não é vista como algo previamente fixado e imutável; pelo contrário, verifica-se, em sua práxis, uma flexibilização constante que se estende e se desloca em zonas cada vez mais amplas da vida social, “em que o soberano entra em simbiose cada vez mais íntima não só com o jurista, mas também com o médico, com o cientista, com o especialista, com o padre" (AGAMBEN, 1998, p. 118). 
Tradicionalmente, o poder disciplinar, paradoxalmente, se exerce tornando-se invisível, o que se vê, se mostra e se manifesta, encontra o princípio da sua força no movimento com o qual se exibe. Logo, aqueles sobre os quais o poder é exercido é irrelevante, todavia, aos que se submetem a ele, impõem-lhes uma obrigatoriedade quanto à constatação da sua visibilidade; visibilidade do poder. Na disciplina, o poder jamais é visto, são os súditos que têm que ser vistos. Ora, é o fato de ser visto, constantemente, de sempre ser visto, que mantém o sujeito como indivíduo disciplinar, "seu resultado é um arquivo inteiro com detalhes e minúcias que se constitui no nível dos corpos e dos dias. O exame que coloca o indivíduo num campo de vigilância o situa igualmente numa rede de anotações escritas; compromete-os em toda uma quantidade de documentos que os captam e os fixam" (FOUCAULT, 2014, p. 185-187).

A história mostrou e ainda nos mostra a maneira árdua pela qual se deu a instituição dos direitos humanos. Reivindicações e imposições ocorreram mediante um processo longo e contínuo de lutas violentas e às vezes revolucionárias em prol de um reconhecimento digno. À luz dos desafios históricos já enfrentados, ainda sim, a sociedade contemporânea convive com situações que reclamam novas atualizações concernentes às dimensões dos direitos fundamentais que têm por essência a dignidade humana (SILVA, 2015, p. 104). Por certo, o Estado constitucional democrático de direito jamais foi obra do acaso, algo que surgiu espontaneamente. Sua instituição se deu com o status jurídico reivindicado pelos cidadãos, ou seja, com o status que os cidadãos assumem em uma ordem política autocriada (HABERMAS, 2001, p. 110). Para Habermas, “o reconhecimento reivindicado pelo cidadão vai além do reconhecimento moral recíproco de sujeitos que agem de modo responsável. Ele tem o significado robusto do respeito exigido pelo status próprio merecido" (HABERMAS, 2012, p. 21).

3. A TESTEMUNHA. Haveria um sentido?

De minha parte, tinha decidido firmemente que, independente do que me viesse a acontecer, não me teria tirado a vida. Queria ver tudo, viver tudo, fazer experiência de tudo, conservar tudo dentro de mim. Com que objetivo, dado que nunca teria tido a possibilidade de gritar ao mundo aquilo que sabia? Simplesmente porque não queria sair de cena, não queria suprimir a testemunha que podia me tornar (AGAMBEN, 2014, p. 25.).

Ao lidarmos com o conteúdo das matérias existenciais no campo nocional próprio da vítima, evidentemente, nos depararemos com significativas dificuldades de ordem 
principiológicas. Ora, a primeira dificuldade que nos deparamos vem à baila quando evocamos os direitos da vítima para estruturar o sentido primevo da pena. Aqui, com frequência, encerra-se o grande ponto nevrálgico que elucida o ponto negro da vingança. Para a filosofia do direito, a constituição dum sentido da pena pública operou-se segundo um gesto de ruptura. Logo, punir, seja para recordar a lei, reeducar o indivíduo ou quem sabe para proteger a sociedade, deveras, seja, antes de tudo, anular todo intento e todo aspecto de vingança (GROS, 2001, p. 112), de retribuição ipsis facto. Obviamente, ao possibilitar a participação ativa da vítima no processo penal, certamente poderíamos incorrer, descabidamente, na prática que insta o fomento à vingança, ao que, por conseguinte discorreria o desfecho do caos cíclico.

O caráter vingador - sentido um tanto quanto articulado de fazer com que o outro sofra em iguais proporções o sofrimento que ele próprio proporcionou a outrem - é identificado pelo relevo que explicita as figuras negativas do ódio, da malvadez, da humilhação e da lembrança dolorosa. Portanto, afirmar do direito penal que ele deveria ajudar a vítima, poderia, até certo ponto, soar negativamente dando a entender que o sofrimento da vítima só poderia ser aliviado desde que na mesma medida fossem determinados aflições ou castigos àquele que lhe agrediu. Por certo, estaríamos dando ares à equivalência sinistra contraditória de justiça: já sofri o bastante, necessário é que ele também sofra o bastante, ao que somente o sofrimento sentido daquele que me fez sofrer poderia apaziguar-me em relação ao sentimento de fúria e assim me curar.

Vejamos, a exigência deste sofrimento torna-se pública, o que se busca, como se vê, é que aos olhos de todos aqueles seja desacreditado. Com isso, constata-se que estamos diante do universo do ódio, um universo posto na sua forma pública, certamente ao fim e ao cabo do sofrimento da vítima produz-se, ainda mais sofrimento e, por conseguinte, outra vítima, uma vez que o que qualifica uma vítima como vítima é precisamente seu sofrimento.

Para um real e verdadeiro exame do homem e da realidade que o circunscreve, a consciência, não restrita aos pressupostos psico onto-deontológico, examinada a partir da esfera que compõem a integralidade do homem perante si mesmo e perante os demais, bem como a realidade em que este está situado, a consciência quando suscitada estabelece uma relação dialética frente todo conteúdo fenomenológico cognitivo, seja a fim de contemplá-lo ou com um fim a ser atingido, ou seja, ou percebe e aprende, ou percebe e quer. Percepção e querer - wollen - configuram-se como orientações viscerais do espírito, sempre pressupostas na estrutura cognitiva. 
A evolução espiritual do homem, o seu dinamismo, erige-se, comumente, na premissa de que a ação instintiva torna-se ação volitiva, isto é, na consciência reconhecemos a utilidade da ação instintiva, de modo que e a cognoscibilidade do fim converter-se-á no móvel da atuação. Com razão, podemos afirmar que pela ideia do fim obteremos a real e clara distinção daquilo que se pode definir como sendo uma ação volitiva duma ação impulsiva. Com a ideia do fim, podemos compreender o quanto o impulso deve se submeter ao fim, bem como, as medidas nas quais a ação, deveras, moldar-se-á a este. Neste sentindo, estamos afirmando, já adiantou Liszt,

Quanto mais claramente se conhece o fim, quanto mais perfeitamente se leva a termo a adaptação consciente, quanto mais se propõem fins remotos e indiretos, no lugar de fins diretos e mais próximos, e, por último, quanto mais se submete a ação integral com seus atos parciais a um só fim supremo que, talvez, transcenda a existência do indivíduo, tanto mais perfeita será a evolução, cuja última meta, ou seja, a total concordância da vontade individual com a vontade coletiva, deve-se estabelecer como ideal, mas que exatamente por isso não ocorreu (LISZT, 2005, p. 33).

Quando, objetivamente, tentamos formular um fim ao qual o direito se presta como tal, infindas interpretações já foram apresentadas. O Processo de Kafka foi e ainda é, metaforicamente, um campo, um laboratório de significado absolutamente relevante fronte a questão posta. As interpretações daí extraídas ora sublinham seu caráter profético-político (a burocracia moderna como mal absoluto), ora um aspecto teológico (o Tribunal é o Deus desconhecido) e ainda, outro biográfico (a condenação seria a doença na qual Kafka tinha consciência de estar acometido). Até então, às interpretações que foram dadas, pouco se falou sobre o aspecto da lei que se apresenta unicamente na forma do processo. Na opinião comum, a natureza do direito, aqui, não se apresenta como norma, julgamento ou mesmo o processo. No ano de 1983, a pedido do editor Einaudi, Levi, em sua tradução, trouxe as seguintes observações:

Se a essência da lei - de toda lei - é o processo, se todo direito (e a moral que está contaminada por ele) é unicamente direito (e moral) processual, então execução e transgressão, inocência e culpabilidade, obediência e desobediência se confundem e perdem importância. "O tribunal não quer nada de ti. Acolhe-te quando vens e te deixas partir, quando vais embora". A finalidade última da norma consiste em produzir um julgamento; este, porém, não tem em vista nem punir nem premiar, nem fazer justiça nem estabelecer a verdade. O julgamento é em si mesmo a finalidade, e isso já foi dito - constitui seu mistério, o mistério do processo (AGAMBEN, 2014, p. 28).

À luz da natureza auto-referencial assumida pelo julgamento, onde a pena não mais vista como consequência sua, antes sim, esta se resume naquele, temos que a totalidade da 
pena se encerra no julgamento. Isso significa que a sentença de absolvição é a confissão de um erro judicial, onde cada um é intimamente inocente, mas que o único verdadeiro inocente não é aquele que obtém uma sentença favorável que o absolve de um crime, antes sim, o verdadeiro inocente seria aquele que passa pela vida sem um julgamento.

No ano de 1971, na ocasião de um debate que discorria sobre a possibilidade ou não do projeto dum tribunal popular, Foucault expunha suas críticas ao modelo de justiça (tradicional) oriunda dum tribunal institucional. Em suas observações Foucault já nos orientava quanto à necessidade de nos desvincularmos da crença reducionista que vincula a ideia de justiça suscitada na forma do tribunal institucional. A problemática que está posta não se refere à possibilidade e em que condições pode haver um tribunal popular; e sim, a grande questão ainda pendente de solução, em primeira ordem, seria: no horizonte da justiça popular e dos atos de justiça popular, um tribunal ocuparia qual lugar? Nesta perspectiva, constata-se que no pensamento de Foucault o tribunal não representa em primeira e última instância a expressão natural da justiça popular, mas pelo contrário, "tem por função histórica reduzi-la, dominá-la, sufoca-la, reinscrevendo-a no interior de instituições características do aparelho do Estado" (FOUCAULT, 1996, p. 19).

Consoantes observações até então apontadas, nos salta aos olhos a inquieta perplexidade denunciada pelo jus filósofo italiano Agamben. Sendo verdade aquilo que se leu, precisamente é possível que os processos (Nuremberg) sejam responsáveis pela confusão das inteligências que, durante decênios, impediu de se pensar Auschwitz na sua realidade concreta. Não obstante a denunciada insuficiência notória dos processos, ainda assim, de certa forma contribuíram para difundir a ideia de que aqueles problemas indeléveis estavam superados. Ora, as sentenças foram dadas por julgadas, de modo que as provas das culpas estavam ali definitivamente postas. Contudo, decorridos alguns decênios, parece-nos ainda não se olvidar dizer estarmos surpresos que o direito não havia esgotado os problemas ali denunciados, do contrário, este se mostrou tão grande ao ponto de pôr em questão o próprio direito e de levá-lo à bancarrota (AGAMBEN, 2014, p. 28).

O que nos parece decisivo, não se trata exatamente de afirmarmos acertadamente poder ou não o direito emitir um julgamento, antes sim, salientarmos que as duas coisas não podem ser confundidas, que o direito não pretenda esgotar toda a questão. Partimos duma premissa que sustenta uma consistência não jurídica da verdade, donde a questão de fato não poderá ser reduzida à mera questão de direito, sobretudo, interpretada como tal. Deste modo, caberá à vítima, precisamente, lidar com aquelas ações humanas que antecedem e 
transcendem a realidade do direito, estas postas equidistantes dos fatos reais, todavia assentada na órbita do processo.

$\mathrm{Na}$ literatura jurídica clássica (latim) encontramos dois termos jurídicos ligados ao substantivo testemunha que denotam conotações etimológicas diferentes. O primeiro deles, testis, do qual deriva testemunha que no seu sentido etimológico denota-se aquele que se põe como terceiro num processo ou em um litígio instaurado entre duas pessoas. $\mathrm{O}$ segundo, supertes, faz alusão àquela testemunha local, aquela que presenciou os fatos e que deles é sabedora dos mínimos e da totalidade dos detalhes, visto que conhece todo deslinde dos fatos. A figura do primo Levi não se relaciona ao testis, um terceiro. Levi vivenciou os algozes de Auschwitz, de modo que em todos os sentidos o mesmo pode ser identificado como um supérsteti. Contudo, não obstante a instauração dum processo, ainda assim, certamente isso não tornará diminutas as exposições quanto à realidade dos fatos testemunhadas por Levi, ou seja, o processo em si não comprometerá seu testemunho que fora suscitado e sentido na pele sob o sol e sob a temperatura que cobria o chão aterrorizador de Auschwitz. Levi reconhece sua impossibilidade à concessão dum perdão, aliás o mesmo afirma que nunca arrogou a condição de agir como juiz visto que, para o mesmo, isso jamais seria possível, deste modo, jamais teria poder para conceder o perdão: "estou sem autoridade" (AGAMBEN, 2014, p. 27).

Ao que tudo indica, nos parece que aquilo que lhe interessa, enquanto testemunha, seria a transcendente zona obscura que torna impossível o julgamento. Aqui, vítimas se tornam carrascos, e os carrascos se tornam vítimas "vítimas e carrascos são igualmente ignóbeis; a lição dos campos e a fraternidade da abjeção” (AGAMBEN, 2014, p. 27).

$\mathrm{O}$ materialismo histórico, bem como o historicismo filosófico mostrou o quanto às análises formuladas sobre as categorias éticas e as categorias jurídicas foram até certo ponto tácitas e equivocadamente confundidas. Os equívocos saltam aos olhos nitidamente quando as premissas oriundas do campo da moral e da religião são de alguma forma contaminadas com o direito. Culpa, responsabilidade, inocência, julgamento, absolvição, todas essas expressões trazem, ainda que de forma subjacente, conotações jurídicas, ao que de certa forma compromete o sentido etimológico de cada termo; assim, usá-las sem a devida precaução específica certamente poderíamos incorrer em erro epistemológico. Comumente, alguns juristas afirmam que o direito não tende, em última análise, ao estabelecimento da justiça, nem sequer o da verdade, busca unicamente o julgamento. Toda e qualquer dúvida que possa surgir contra esse argumento tenderá ao insucesso pela força da coisa julgada, que diz respeito 
também a uma sentença injusta. Ora, com a res judicata, temos aí o fim do direito com a qual a sentença substitui o verdadeiro e o justo (AGAMBEN, 2014, p. 28).

Testemunhar ou tornar-se uma testemunha pressupõe razões que nalgumas vezes ecoarão nos alicerces sólidos da moral fazendo-a reconfigurar a partir de razões temerosas, pelo seu caráter revelador, porém compreensivo considerando seu aspecto onto-teleológico. As razões e os motivos às quais se tem uma testemunha correspondem, até certo ponto, à ambição pela verdade a pretexto dum julgamento leal, correspondente às realidades de um fato. Quando testemunhamos a respeito de algo, o fazemos a pretexto de quais ambições? Deveras, a decisão de se tornar um supertestes consiste sobre razões ditas ainda maiores do que aquela que meramente almejam revelar a veracidade dum fato. Essas razões sobressaltam o anúncio do terror, não sucumbe ao medo da morte, antes sim, transpassa este, eternizandose como conteúdo ou substância da realidade testemunhada.

De minha parte, tinha decidido firmemente que, independente do que me viesse a acontecer, não me teria tirado a vida. Queria ver tudo, viver tudo, fazer experiência de tudo, conservar tudo dentro de mim. Com que objetivo, dado que nunca teria tido a possibilidade de gritar ao mundo aquilo que sabia ? Simplesmente porque não queria sair de cena, não queria suprimir a testemunha que podia me tornar (AGAMBEN, 2014, p. 25).

Certamente, muitas são as razões as quais se tem uma testemunha, as quais se fala duma suposta verdade a respeito de algo. Na maioria das vezes não conseguimos extrair os fins ambicionados num testemunho, quando a imparcialidade foge à regra e a consciência descomprometida corrompe o conteúdo mínimo da ética, testemunhar já não mais se justifica, pois o que se tem trata-se de uma sede de vingança que se funda sobre a identidade de vítima. Não nos parece controverso que o conceito de responsabilidade, ainda quando usado fora do campo jurídico, por este está irremedialvelmente contaminado. Atenuar ou mitigar a tomada de consciência fronte uma responsabilidade jurídica, pareceu, até certo ponto, consequência resultante da auto-definição assumida pela ética, pela política e pela religião ao expandirem a zona de atuação adentrando no terreno da responsabilidade jurídica. A verdade é que não se pretendeu reconfigurar uma outra responsabilidade, mas sim, buscou-se ampliar as zonas de não-responsabilidade. Ora, de alguma forma, isso poder-nos-ia soar com certa incongruência levando a crer que estaríamos diante da ilibação da impunidade, obviamente que isso não nos pareceria eticamente adequado. Por outro lado, isso significou - em se tratando da ética - arrostar-se com uma responsabilidade infinitamente maior do que aquela que deveras pudéssemos, quem sabe, assumir. No máximo, destaca Agamben, "podemos serlhe fiéis, ou seja, reivindicar a sua não-assumibilidade" (AGAMBEN, 2014, p. 30). 
A lição ética de vingança, tal como Aristóteles e Nietzsche apresentam, ressalta o anseio da vingança como ato público de manifestar seu poder, onde a partir dessa manifestação recuperar-se-ia a inquietada estima de si. No sentido aristotélico, com a vingança buscar-se-ia a recuperação pública da atividade. O termo antipoiei, dizia Aristóteles: "vingar-se é exercer uma atividade de retorno" (ARISTÓTELES, 2005, 1378b). A vingança, ao que nos parece, num primeiro momento compreende-se como uma antipoiêsis, isto é, afirmação de poder de si e atribuição de valor em relação àquele que a põe em causa. Com efeito, o que um crime, uma injúria, uma ofensa, um delito despedaçam é para já autoconfiança, a autoestima na sua integridade, uma integridade dinâmica e vital.

A descoberta inaudita que Levi obteve em Auschwitz reporta a um assunto refratário sob qualquer parâmetro de responsabilidade. Denominada como zona cinzenta, Levi conseguiu isolar aquilo que mais tarde seria identificado como sendo um novo elemento ético. Essa cadeia cinzenta contempla as conjunções entre vítimas e algozes, ao passo que o oprimido de tornar opressor e o carrasco, por sua vez, se torna vítima. Chega-se a uma zona nebulosa, onde temos uma alquimia opaca, incessante onde o bem e o mal, e com eles toda essência da ética tradicional, alcançam o seu ponto de fusão. "Trata-se, portanto, de uma zona de irresponsabilidade e de impotentia judicandi, que não se situa além do bem e do mal, mas está, por assim dizer, aquém dos mesmos" (AGAMBEN, 2014, p. 30-31).

\section{A IGNOMINIA E A ÉTICA DO SER}

As estruturas fundamentalmente relacionais das nossas existências seria o arcabouço, o depósito donde se funda o pressuposto da ética. O bem viver pressupõ e uma justa distância em relação ao outro, porém, essa justa distância seria, deveras, a negação imediata da total separação e da fusão. Assim, quer-se falar duma distância constitutiva da relação com os outros.

Como sujeitos éticos do direito, não pertencemos um ao outro, nem estrangeiros, nem parentes, mas sujeitos livres. Mas que será então punir segundo a justiça relacional? A priori, deveríamos considerar que o crime e a agressão não configuram por essa justiça, por assim dizer, transgressão à lei ou um atentado à ordem pública, nem mesmo um sintoma patológico, mas a fratura desta justa distância entre os sujeitos éticos (GROS, 2001, p. 133). Deste modo, é evidente que aquilo que me agride promove estragos na minha vida antes de atingir diretamente à lei, ou seja, aquilo que me fere, que me rouba, me agride, infringe a pressuposta distância invisível que delimita os espaços e separa tudo, ligando-os aos sujeitos 
de direito. Com isso, punir, deveras, seria o ato pelo qual se chegará ao desfazimento deste nó destinado a restaurar, restituindo-a publicamente, a uma distância justa.

Do verbo latino spondeo deriva o termo responsabilidade donde se extrai o sentido epistemológico "apresentar-se como fiador de alguém". No antigo direito romano era comum um homem livre constituir-se como garantia à reparação de um erro cometido por alguém. Com essa práxis surgiu o termo obligatio de conteúdo meramente jurídico e sempre utilizado nas situações onde havia um inadimplemento contratual. Como se sabe, um terceiro, estranho ao negócio jurídico, ficava refém do credor dado o não cumprimento de uma obrigação assumida pelo outro contratante; a pessoa se tornava responsável (sponsor) pelo réu. Logo, o gesto de assumir a responsabilidade não significava outra coisa que não um ato meramente jurídico, equidistante de qualquer pressuposto ético como se pretendeu pressupor até então. Aqui não há que se falar em nobreza, ou benesse alguma, mas sim, um gesto pelo qual alguém se responsabiliza pela inobservância do cumprimento assumido por outro e, deste modo, ficando refém daquele que teve ao seu desfavor o descumprimento de uma obrigação. Dos termos responsabilidade e culpa, extrai-se, conforme aponta Agamben, dois aspectos da imputabilidade jurídica e que só num momento mais tardio foram interiorizados e transferidos para fora do direito. Daí, "nascem à insuficiência e a opacidade de dota doutrina ética que tenha a pretensão de se fundamentar nestes dois conceitos" (AGABEN, 2014, p. 30).

A insuficiência e a opacidade que se fazem ver, todas as vezes que se justapõem as fronteiras que separam a ética do direito, tornam-se evidentes quando estamos diante de situações descritas como culpa objetiva e consciência de conteúdo moral. No processo de Jerusalém o sentido da tese utilizada pelo advogado de defesa do Eichmann, recorre a um argumento que se pretende afirmar nobre sem, contudo, reconhecer a culpa jurídica, “Eichmann sente-se culpado perante Deus, não frente à lei”. Eichmann, conforme se pode provar, teve participação direta no extermínio do judeus. Com o pretexto de livrar os jovens alemães do peso da culpa, o mesmo chegou afirmar que pretendia ser enforcado em praça pública em razão dos seus atos, entretanto, em momento algum assumiu a culpa jurídica, antes sim, somente reconheceu-se culpado perante Deus. Para Agamben (2014, p. 32),

O único sentido possível para este distinguo, tão insistentemente afirmado, consistia em que, com toda evidência, o fato de assumir uma culpa moral parecia frente aos olhos do imputado como algo eticamente nobre, enquanto não estivesse disposto a assumir a culpa jurídica (culpa que, do ponto de vista ético, teria podido ser bem menos grave).

O auto reconhecimento de uma culpa moral destoada duma responsabilidade jurídica soa como discurso meramente retórico, visto que nessa circunstância a moral 
pressuposta segue totalmente desconstituída de significância teleológica reparativa. Mormente, nunca soou como imoral ou antiético o gesto de quem assume para si uma culpa jurídica de que é inocente, pelo contrário, esse ato, aos olhos político e social, sempre nos pareceu tratar de uma gesto nobre; por outro lado, em se tratando de um ato de assumir uma responsabilidade política ou moral porém desvinculada e descomprometida com as consequências jurídicas sempre nos pareceu um ato de arrogância, mera retórica, e ludibriosa demagogia. A confusão entre categorias éticas e categorias jurídicas, aponta Agamben (2014, p. 32),

(...) é, neste caso, absoluta. Está na origem dos numerosos suicídios praticados para escapar de um processo (e não só por parte dos criminosos nazistas), em que a tácita assunção de uma culpa moral teria a pretensão de redimir-se daquela jurídica. Convém lembrar que a primeira responsável por essa confusão não é a doutrina católica, que, aliás, conhece um sacramento cuja finalidade consiste em libertar o pecador com relação à culpa, mas a ética laica (na sua versão moderada e farisaica, que é a dominante). Após ter alçado as categorias jurídicas e categorias éticas supremas e ter, assim, confundido irremediavelmente os papéis, ela ainda gostaria de recorrer ao seu distinguo. Mas a ética é a esfera que não conhece culpa nem responsabilidade: ela é, como o sabia Spinoza, a doutrina da vida feliz. Assumir uma culpa e uma responsabilidade - o que, às vezes, pode ser necessário fazer - significa sair do âmbito da ética pra ingressar no do Direito. Quem procurou dar esse difícil passo não pode ter a pretensão de voltar a entrar pela porta que acabou de fechar atrás de si.

A figura extrema da zona cinzenta fazia surgir num mesmo indivíduo uma figura dicotômica que ora se confundia em opressor, ora se confundia em vítima. Aqueles que atuavam junto ao Esquadrão Especial, eufemismo referente às SS, diariamente ressentiam a resignação daquilo que significou o maior terror deliberadamente acometido à raça humana. Esses deveriam conduzir até as câmaras de gás os prisioneiros, que sempre despidos eram colocados em ordem, um a um, e depois, já no estado de morte, os agentes da SS arrastavam os cadáveres sempre manchados duma tonalidade rosa e esverdeada, dada a inalação do ácido cianídrico, e quando já postos fora das câmaras de gases, aqueles cadáveres estendidos ao chão eram lavados com jatos d'água e, por conseguinte, submetidos a uma cuidadosa revista para ver se ainda havia nos orifícios dos corpos alguma joia escondida, bem como ter seus dentes de ouro extraídos etc.

O horror intrínseco da condição humana estante na zona cinzenta atingia a parte mais densa da consciência humana ao que por certo fazia ressurgir, ainda que de forma tênue, a consciência de si em detrimento da dialética do sofrimento com o outro que sofre. 
Em os “Afogados e Sobrevivente', Levi dá testemunho dessa cruel e descomunal realidade vivenciada por um dos agentes da SS :

\begin{abstract}
"Ao realizar esse trabalho, ou se enlouquece no primeiro dia, ou então se acostuma". Mas o outro disse: "Por certo, teria podido matar-me ou me deixar matar; mas eu queria sobreviver, para vingar-me e para dar testemunho. Vocês não devem acreditar que nós somos monstros; somos como vocês, só que muito mais infelizes". [...] De homens que conheceram essa destruição extrema não se pode esperar um depoimento no sentido jurídico do termo, e sim algo que fica entre o lamento, a blasfêmia, a expiação e o esforço de justificativa, de recuperação de si mesmo. [...]. Ter concebido e organizado os Esquadrões foi o delito mais demoníaco do nacional-socialismo (AGABEN, 2014, p. 34).
\end{abstract}

Levi relata um testemunho de um dos poucos sobreviventes do último esquadrão especial de Auschwitz - Miklos Nyiszli - que tenta testificar em palavras o que significou do ponto da ética e da moral - para a família humana a fábrica de mortos de Auschwitz. Esse relato que ora iremos expor, narra um episódio que testifica, na sua totalidade, a extrema banalização do mal, a mais absurda coisificação do homem, a mais descomunal forma de insignificância do ser, que possa atingir padrões e paradigmas mais baixos da moral ainda não pensados pelo homem, ou seja, jamais visto, jamais ouvido; ainda não pensado. Este contou que assistiu, durante um intervalo de "trabalho", a um jogo de futebol entre SS e representantes do Sonderkmmando.

[...] à partida assistem os outros soldados SS e o resto do Esquadrão, torcendo, apostando, aplaudindo, encorajando os jogadores, como se a partida se desenrolasse não diante das portas do inferno, mas num campo de aldeia (AGABEN, 2014, p. 34-35).

Obviamente, essa partida de futebol significou - e ainda significa -, a conotação máxima daquilo que a mente humana consiga compreender e extrair do termo insignificância. A ignominia, a maior de todas as blasfêmias humanas já pensadas, ocorreram ali, bem ali, aos olhos do homem agora nitidamente indiferente a toda e qualquer ideia, ainda que mínima, em relação à humanidade. Aos olhos desses, o humano já não mais existe, a identidade que permeia uma série de valores e que dá consciência ao homem da sua existência e do seu eu fora subtraída e suplantada à condição dum nada que não mais descreve coisa alguma, eliminando assim qualquer possibilidade, ainda que mínima, de ver e sentir naquele a concepção de sujeito, ou seja, o que se tem e o que se vê nada mais é do que uma espécie de ser vivo destituído de uma identidade própria; a demandada pausa de reflexão para consciência aponta algo agora descrito e posto frente ao olhos como uma coisa uma mera coisa. Agamben, ao se referir àquela partida de futebol, descreve-a como um momento no 
qual teria ocorrido uma breve pausa de humanidade em meio a um horror infinito. "Aquela partida ainda não terminou, é como se continuasse ainda, ininterruptamente [...]. Dela provêm a angústia e a vergonha dos sobreviventes [...]. Se não conseguimos entender aquela partida, acabar com ela, nunca mais haverá esperança" (AGABEN, 2014, p. 35).

Vejamos, o mal do crime não deve ser procurado tão-somente na perturbação do espírito do outro, antes sim, numa desigualdade injustificável criada entre dois indivíduos. A infelicidade que sofreu o queixoso é inseparável e essencialmente física e ética. Concomitantemente afeta seu corpo, sua honra, sua reputação e por último sua consciência de identidade.

\section{CONCLUSÃO}

O algoz e o peso da culpa, quando sentido por aquele que cometeu um delito, tendem fazer com que o criminoso deixe de exteriorizar seus instintos e doravante viva/comporte-se de acordo com a sociedade, agora ressentindo-se, imbuído de culpa e de consciência moral que auto se exclui. Assim, o Direito, ao punir o criminoso, reduz o indivíduo à baixeza do seu ato revitalizada em sua memória, fazendo com que o mesmo se torne um homem de reação, de autocomiseração e culpa. O que nos causaria maior escândalo: punição ou impunidade? A punição, mesmo a legítima, não deixa de ser um escândalo aos olhos dos verdugos e do destino dos condenados comumente ultrajados. Violência ou justiça? A sociedade ainda reivindica uma fundamentação convincente - do plano de vista racional - que diz respeito ao conteúdo qualitativo do direito. Os verdugos e a violência cunhadas na aplicação do direito revelam o terror de um paradoxo que se propaga pelo viés do biopoder fomentando a ideologia dos corpos descartáveis.

Neste fluxo contínuo do medo à piedade, do medo por si ao receio do outro, havemos de resignar-nos a ver o destino do homem democrático submetido a essa oscilação trágica de uma paixão por seu oposto, porque a ele nada lhe importa do que assegurar, a todo custo, a proteção adequada ao indivíduo, seja este vítima ou autor. Hesitado por alguns, os horizontes da pena foi até certo ponto um itinerário ultrajado, senão, colocada no sótão das reflexões da ética, da filosofia e da sociologia jurídica. Este caminho escarpado que de forma sucinta reabríamos em linhas supra, buscamos encarar sob outro ponto de vista, que não o da criminilogia universitária, mas sim, pelas lentes da biopolítica e do biopoder. A comunidade dos não-cidadãos são constituídas por corpos destituídos de alma humana, assim, são identificados pelo auspício da áurea que advém do encanto nebuloso e cinzento (ponto cego) 
da biopolítica e do biopoder. A vida nua, meros seres biológicos, retrata a mórbida do biospolitikos e o fim do bios-theoretikós.

\title{
THE POWER AND LAW
}

An approach from the perspective of biopower

\begin{abstract}
Analyzing aspects of power as forms of domination and their relationship with politics and law is the subject of this article. In this sense, our article anticipates its reflections by raising some questions beforehand, such as: would there be any sense for us to think of a coexistence between power, politics and law? Would the existence / permanence of the right be compromised if divorced from a coexistence of power? Taking the work of Hannah Arendt as a theoretical reference, our article directs its analyzes to the systemic conception of law and politics linked to the concept of power approached in Luhmann's thought.
\end{abstract}

KEYWORD: Power. Law. Biopower.

\section{REFERÊNCIAS}

AGAMBEN, Giorgio. O que resta de Auschwitz. São Paulo: BOITEMPO, 2014;

AGAMBEN, Giorgio. O poder soberano e a vida nua. Trad. António Guerreiro. Lisboa: Presença, 1998;

ARENDT, Hannah. Sobre a Violência. Trad. André Duarte. $8^{\mathrm{a}}$ Ed. Rio de Janeiro: Civilização Brasileira, 2017a;

Perspectiva, 2017b;

Entre o passado e o futuro. Trad. Mauro W Barbosa. $8^{\text {a }}$ Ed. São Paulo:

Sobre a revolução. Trad. Denise Bottmann. $3^{\text {a }}$ Reimpressão. Rio de Janeiro: Civilização Brasileira, 2017 
ARISTÓTELES, Arte retórica e arte poética. Tr.: A. P. de Carvalho. Rio de Janeiro: Ediouro, 2005;

FERRAZ JUNIOR, Tercio Sampaio. Estudos de Filosofia do Direito. $3^{\text {a }}$ Ed. São Paulo: Atlas, 2009;

FOUCAULT, Michael. VIGIAR E PUNIR. Nascimento da prisão. Trad. Raquel Ramalhete. Petrópolis: Vozes, 2014;

FOUCAULT, Michael. Microfísica do poder. $12^{\mathrm{a}}$ Ed. Trad. Roberto Machado. Rio de Janeiro: Graal, 1996;

FOUCAULT, Michael. La volontà di saberi. Trad. Mauro Bertani, Feltrinelli. Milano, 1984;

GROS, Frédéric. Punir é transformar um sofrimento em infelicidade. In: GARAPON, Antoine, et all. Punir em Democracia. Trad. Jorge Pinheiro. Lisboa: Instituo Piaget, 2001;

HABERMAS, Jürgen. Sobre a constituição da Europa. Trad. Denilson Luiz Werle, et all. São Paulo: Unesp, 2012;

Seligmann Silva. São Paulo: Littera Mundi, 2001;

HEGEL, G.W.F. A fenomenologia do espírito. Trad. Henrique Lima Vaz. São Paulo: Abril, 1974, p. 18-19.

LISZT, Franz Von. A ideia do fim no direito penal. Trad. Hiltomar Martins Oliveira. São Paulo: Rideel, 2005;

LUHMANN, Niklas. Introdução à Teoria dos Sistemas. Trad. Ana Cristina Arantes Nasser. $2^{\mathrm{a}}$ Ed. Petrópolis: Vozes, 2010.

EL DERECHO DE LA SOCIEDAD. Trad. Javier Nafarrate Torres, México:

Universidad Iberoamericana, 2005.

. Poder. Trad. Martine Creusot de Rezende Martins. Brasilia: Universidade de Brasilia, 1985.

SILVA, Luciano Braz. Por que a dignidade humana? In: Responsabilidade e futuro: bioética, biopolítica, biopoder e os desafios para reflexão e ação. (Org) JUNIOR, Oswaldo Giacoia, et all. São Paulo: LiberArs, 2015.

Trabalho enviado em 09 de outubro de 2018

Aceito em 14 de março de 2019 